Kapás Judit

\title{
A tulajdonjogok legális versus illegális védelme, avagy hogyan vezetnek a gyenge állami intézmények a maffiaszerü szervezetekhez
}

\section{Bevezetés}

A felső-ausztriai Steyr városa 2005. júliusában hetedik alkalommal adott otthont a 6 napos European Science Days in Steyr ${ }^{l}$ (EDS) nyári egyetemnek, amely az egyik legrangosabb a közgazdasági nyári egyetemek között Európában. 1999-től minden év júliusában valamely közgazdasági elméleti kérdés köré szerveződnek az előadások és a konzultációk a leghíresebb amerikai és európai professzorok részvételével. A programot minden esetben nagy gondossággal állítja össze a nyári egyetem tudományos igazgatója, aki mindig az adott téma nemzetközileg elismert szakértője. Az előző hat alkalmat mainstream közgazdaságtani témáknak szentelték a szervezők, de izgalmas, egyedi kontextusba helyezve azokat. Így többek között 2001-ben a gazdasági élet társadalmi és pszichológiai meghatározóinak tanulmányozása keretében az emóciók és a korlátozott racionalitás témaköre kapott kiemelt szerepet, majd a következö évben a gazdasági növekedés elméletét az értékek és a társadalmi haladás kérdésével kapcsolták össze, tavaly pedig a szervezetek közgazdaságtana keretében a piaci és a vállalaton belüli ösztönzők, valamint az autoritás álltak a középpontban. Ez idáig az előadók között volt, a teljesség igénye nélkül, Philippe Aghion (Harvard University), George Baker (Harvard University), Masahiko Aoki (Stanford University), Daron Acemoglu (MIT), Bruno Frey (University of Zurich), Luigi Zingales (University of Chicago), Robert Gibbons (MIT). Tiszteletreméltó lista.

A 2005. évi nyári egyetem témája nem illeszkedik a fentebb említett sorba, legalábbis abban a tekintetben, hogy az ma még nem tekinthető mainstream kutatási iránynak, bár, ahogy azt majd igyekszem megmutatni, annak kellene lennie, és valószínúleg a közel jövőben azzá is válik. A nyári egyetem címe Extra-legal Protection, Organised Crime and Economics volt, a tudományos igazgató pedig Diego Gambetta professzor (Oxford University). A téma több szempontból is rendkívül izgalmas. Egyrészt, valódi multidiszciplináris kérdés, amelyet tudományosan elsőként nem is a közgazdaságtan, hanem más társadalomtudományok (szociológia, politológia, jog) kezdték 
vizsgálni. Másrészt, a témában közgazdaságtani kutatások csak az utóbbi évtizedben indultak el, legalábbis célzottan. Harmadrészt, különösen a fejlődő országok számára lenne fontos az elméletből olyan, politikát is alakító, következtetéseket levonni, amelyek segíthetik a szervezett bünözés elleni harcot. És végül a maffia ${ }^{2}$ mitikus és titokzatos jellege is ösztönzi az embert a téma tudományos megértésére.

A nyári egyetem igazgatója, Diego Gambetta szociológusprofesszor évtizedek óta kutatja a maffia müködését és azt vallja, hogy a közgazdaságtan hozzájárulása nélkül nem lehetséges további áttörő előrelépés a szervezett bünözés megértésében. Kétségtelenül ez egy igazi tudós álláspontja, aki fontosabbnak tartva a tudományos megértést képes túllépni saját tudományága partikuláris érdekein. Ennek szellemében Gambetta professzor a program legalább háromnegyedét a közgazdasági elméletnek szentelte és kiváló közgazdászprofesszorokat hívott meg előadónak.

Az alábbiakban nem krónikaszerü beszámolót nyújtok a nyári egyetemről, sokkal inkább egy bevallottan szubjektív válogatást a felvetett közgazdasági elméletekből. Célom, hogy rövid „kitekintőt” adjak - ahogy azt e rovat címe is sugallja - arról, hogy milyen új utakon halad a modern közgazdaságtudomány, s nincsenek kétségeim afelől, hogy a szervezett bünözés közgazdaságtana egy eme új utak közül. Így a nyári egyetemen felvetett elméletek között - saját „,ízlésemnek” megfelelöen - elsősorban az intézményi közgazdaságtanra koncentrálok: arra a kérdésre, hogy a gyenge intézmények miért és hogyan vezetnek a maffiaszerű szervezetek megjelenéséhez. ${ }^{3} \mathrm{E}$ kérdés egyrészt az intézmények általános elemzését jelenti, melyet Avner Greif (Stanford University) az új intézményi közgazdaságtan egyik meghatározó szaktekintélye három előadásában vázolt fel gazdaságtörténeti példákon keresztül. A probléma másik aspektusa az irányítási formákra vonatkozik, melyekről Avinash Dixit (Princeton University) professzor tartott három előadást.

\section{Mi köze a maffiának a közgazdaságtanhoz?}

A piacok megfelelő működése a tulajdonjogok tiszteletben tartásán alapul. Ennek hiányában egyesek egyszerủen csak elrabolják a mások által termelt javakat. Ez az állapot elöbb vagy utóbb odavezetne, hogy senki sem termelne. Világos tehát, hogy a tulajdonjog szentsége nélkül nem létezhet gazdaság, s ezért kell a közgazdaságtannak elemeznie a szerződéses mechanizmusokat és a tulajdonosi jogok kikényszerítését. Ez a kutatási irány azonban csak a 70-es évektől az új intézményi közgazdaságtan kialakulásával bontakozott ki, többek között Douglass North Nobel-díjas közgazdász munkássága nyomán. Az elmúlt több mint 30 évben az intézményi kutatások hihetetlen fejlődésen mentek keresztül és mára a mainstream részévé váltak. Az új intézményi közgazdaságtan éppen azokat az intézményeket kapcsolja be a megértésbe, amelyeket a standard közgazdaságtan adottnak tekintett, és ennek okán nem vizsgált.

A fejlett országokban, ahol az állam jól „ellátja” a tulajdonosi jogok védelmét, a szervezett bűnözés inkább kriminológiai kérdés (kivéve Szicíliát és Észak-Îrországot).

\footnotetext{
${ }^{2}$ Az alábbiakban - kis kezdőbetüvel írva - maffia alatt általában a szervezett bünözői csoportokat értem, nem csupán a szicíliai Maffiát.

${ }^{3}$ Igy többek között olyan rendkívül izgalmas kérdések is kimaradnak az áttekintésböl, mint Mancur Olson 'stationary bandits' elmélete, a korrupció és a védelmi szolgáltatások kapcsolata, valamint a szervezett bünözés piacának piaci szerkezeti ('industrial organization') elemzése.
} 
De még ezekben az országokban is, nem beszélve persze a fejletlen országokról, megjelentek alternatív formák a tulajdonjog védelmére illegális piacokat teremtve. Ezek egyrészt azokon a területeken alakultak ki, amelyeket az állam nem ért el, vagy nem akart elérni. Az állam tulajdonosi jogokat kikényszerítő intézményei mellett tehát kialakultak különböző privát intézmények a tulajdonosi jogok védelmére. Ilyen privát védelmi intézmény a maffia. ${ }^{4}$ Ezt a nézetet elsőként Gambetta (1993) fejtette ki a szicíliai Maffiáról írt híres könyvében, s erre épül a maffia közgazdasági megközelítése.

Gambetta szerint a maffia oligopol vállalatok csoportja, amely védelmi szolgáltatást nyújt a piacon. A maffiózók „védelme” alatt azt kell érteni, hogy megvédik ügyfeleiket az erőszaktól, lopástól, csalástól, vagy a legális versenytől. A szervezett bünözés e megközelítése gyökeresen eltér két alternatív nézettől. Az egyik szerint a maffiózók olyan vállalkozók, akik az illegális javak (drogok, fegyverek, prostituáltak) piacán müködnek, a másik nézet szerint legális javakkal kereskednek, de erőszakosan. Mindezekkel szemben Gambetta felfogása úttörö jellegü, s utat nyitott a közgazdasági elemzésnek.

Gambetta professzor elmélete két szálon köthető a közgazdaságtanhoz. Az egyik szál az a koncepció, miszerint a maffia vállalatszerű intézmény: a maffiózók vállalkozók, akik a piacon müködnek és profit elérésére törekednek. Másrészt, mivel a szervezett bünözés egy alternatív tulajdonjogot kikényszerítő (tágabban védelmi szolgáltatást nyújtó) szervezet az állammal szemben ${ }^{5}$, nem lehet azt úgy elemezni, hogy megkerüljük az állam szerepét. Vizsgálni kell tehát a „föld feletti” (állami) és a „föld alatti” védelmi piacok kapcsolatát: a tulajdonosi jogok védelmének „föld alatti” piacai a „föld feletti” hiányosságok miatt alakulnak ki. Így vezetnek a gyenge intézmények a szervezett bünözéshez. ${ }^{6}$

A maffia tevékenységének vállalatszerü aspektusait hangsúlyozva a maffia és az állam természetének különbözősége kerül megvilágításba, hiszen a vállat és az állam különböző dolgok. Ezzel szemben a második szál a maffia és az állam hasonló természetére utal: tág értelemben mindkettő ugyanabba a jelenségcsoportba tartozik. Elöször is, mert mindkettő ugyanazt a szolgáltatást nyújtja, nevezetesen a tulajdonjogok védelmét, másrészt, mert mindkettő monopólium akar lenni és „adóztat”, azaz ebben az értelemben „nem önkéntes alapon szerzik ügyfeleiket”.?

${ }^{4}$ Hiteles ábrázolást adnak a híres maffia filmek, például a Keresztapa-trilógia vagy a Fedőneve: Donnie Brasco.

${ }_{5}^{5}$ Meg kell jegyezni, hogy a védelmi szolgáltatások illegális piacát, szemben a legálissal az erőszak alkalmazása jellemzi. Ez azonban bizonyos területeken (például prostitúció, alkohol, könnyü drogok) az állami korlátozásokból következik, hiszen a maffia számára az eröszak eszköz, és nem cél. Világos, hogy ezekben az esetekben a korlátozás feloldása az illegális védelmi piac és az erőszak megszünéséhez vezetne. Azt hiszem elég, ha Hollandia példáját tekintjük, ahol a prostitúció és a könnyű drogok legalizálása nem csak a bünözés egy részét szorította vissza, de például a kábítószer fogyasztók számát sem növelte.

${ }^{6}$ Napjainkban a szervezett bűnözői csoportok térnyerése rendkívüli mértékű az átmeneti országokban, különösen Oroszországban. Az átmenet az intézményrendszer jelentős átalakításával jár, és legtöbbször a piac müködéséhez szükséges intézmények némelyike csak lassan, vagy egyáltalán nem alakult ki. Ez a táptalaja a maffiaszerü csoportok tevékenységének, így az orosz maffiának is.

7 Természetesen számos különbség létezik az állam és a maffia között, a leglényegesebb a legitimációval kapcsolatos. A reális legitimáció arra vonatkozik, hogy a "védelmezetteknek" vannak-ejogaik a "védelmezőikkel" szemben. Ez azt jelenti, hogy az államot kényszerítő (korlátozó) intézmények léte és hatékonysága kulcsfontosságú mióta csak állam létezik, hiszen - többek között - ezek garantálják a „védelmezettek” szabadságát. 


\section{Állam versus maffia}

Hogyan és milyen intézmények alakulnak ki, és ezek közül melyeket biztosítja az állam? Ez a kérdés áll Avner Greif kutatói munkásságának középpontjában, és ezzel foglalkozott a nyári egyetemen tartott előadásaiban is. Óriási szellemi élmény volt Greif profeszszort hallgatni, aki bámulatos módon elemzi - a mainstream közgazdaságtan formális és játékelméleti eszközeit is alkalmazva - az intézmények szerepét és dinamikáját többek között a feudális Itáliából vett példákon.

Genova felemelkedésének és bukásának (1096-1339) története (Greif 2005a) az állam és a vele szemben álló klánok (mai szóval maffia) viszonyában mutatja be azokat az intézményeket, amelyek segítették (vagy nem segítették) az államot kényszerítő hatalmának megőrzésében. A 11. században Genova egyrészt a kalózkodásban, másrészt a külföldi kereskedelmi privilégiumok megszerzésben volt érdekelt. 1099-ben a városállam politikai értelemben is megszerveződött: két klán létezett, akik konzult választottak. A klánok és azok normái jelentették azokat az intézményi kereteket, amelyekben az új intézmények kialakultak. A klánok között „navigáló” koordinatív állam egyensúlya hosszú ideig (1154-ig) fennállt. Greif ezt az egyensúlyt „kölcsönös elrettentési egyensúly"-nak nevezi. Ebben mindkét klán azt hiszi, hogy nem érdeke megtámadni a másikat, mert - tekintettel a másik katonai erejére, a támadás költségére és a háborúskodás miatt kieső kalózkodásból származó jövedelemre - az nem járna „profittal”. A konzuli rendszer stabilitását biztosító intézmény az elrettentési költség (deterrence cost) volt.

A gazdasági tevékenység azonban a kereskedelmi privilégiumok megszerzésével szemben a kalózkodás irányába tolódott el ${ }^{8}$, amely a fennálló intézményeket már túlhaladottá tette, mert a klánok egyre nagyobb kényszerítő hatalom megszerzésében voltak érdekeltek. Mindez azt jelenti, hogy az addig fennálló intézmények saját magukat aknázták alá, önmegsemmisítőkké váltak. 1164-ben összeomlott a konzuli rendszer és polgárháború tört ki. Mivel a klánok képtelenek voltak együttmüködni, külső hatalmat hívtak a város vezetésére. Ez a személy volt a podesta ${ }^{9}$, aki a városállam katonai, bírói és adminisztratív vezetőjeként képes volt egyensúlyi helyzetet teremteni a klánok között. A kialakult hatalmi egyensúly azonban meglehetősen kényes volt: egyrészt olyan intézményekre volt szükség, amelyek képesek voltak elrettenteni a podestát attól, hogy valamelyik klánnal összejátsszon, másrészt, olyanokra, amelyek megakadályozták, hogy a podesta diktátorrá váljon. ${ }^{10}$ Genova prosperitásának második szakaszában (1194-1339) tehát a podesta intézménye garantálta az erős államot, és szorította vissza a klánokat (maffiát). De hasonlóan a konzuli rendszerhez, a podesteria is saját magát ásta alá. ${ }^{11}$

Mi a tanulság Genova történetében? Egyrészt az intézmények változásának dinamikája áll előttünk. Másrészt láthatjuk, hogy bizonyos intézményeknek alapvető szerepük van abban, hogy az állam képes kényszerítő hatalmát gyakorolni, vagyis éppen ezek hiánya vezet oda, hogy a maffia kényszerítő hatalma megnő. Természetesen időtől

\footnotetext{
${ }^{8}$ Érdekes, hogy a "kölcsönös elrettentési egyensúlyban" a klánok nem a kereskedelmi privilégiumok számának növelésében, hanem a kalózkodás fokozásban voltak érdekeltek. Az okokról lásd: Greif (2005a).

${ }^{9}$ A podesta jelentése hatalom ('power').

${ }^{10}$ A podestára vonatkozó szabályok mind eme kényes egyensúly elérését voltak hivatottak szolgálni: a podesta nem lehetett genovai származású, nagyon magas fizetést kapott, nem lehetett üzletiérdekeltsége, hivatali idejének lejárta után el kellett hagynia a várost.

"Az okokról lásd: Greif (2005a).
} 
és kortól függően ezek a „bizonyos” intézmények mások és mások: ami Genovában a podesta volt, az a mai világban valami egészen más.

Greif professzor egy másik előadásában a középkori európai kereskedelem példáján azt is elemezte, hogy hogyan fejlődtek ki azok az intézmények, amelyek a személytelen cserét ${ }^{12}$, s így a piacot támogatják (Greif 2005c). Állítása szerint ugyanis a történelmi tapasztalatok azt bizonyítják, hogy az állam kialakulása előtt a személytelen cserék (piac) nem tudnak fejlődni, mert hiányoznak azok az intézmények, amelyek a szerződéseket hatékonyan képesek kikényszeríteni. Európában a Kommunális Felelősségi Rendszer ('Community Responsibility System') volt az az intézmény, amely ilyen szerződést kikényszerítő intézmény volt, és így a piac intézményi alapját jelentette abban az időben. ${ }^{13}$ A Kommunális Felelösségi Rendszer (CRS) éppen arra jó példa, hogy ha az állam képes hatékony kikényszerítö intézményeket (tulajdonvédelmi intézményeket) biztosítani, akkor a privát védelmi intézmények (maffia) nem alakulnak ki.

A fenti példa az állam által megkonstruált szerződést kikényszerítő intézmények szerepének fontosságára utal. De mi korlátozza az államot abban, hogy ő milyen mértékben korlátozza az egyéneket? Ez magát az államot korlátozó intézményektől függ. Harmadik előadásában Avner Greif az intézmények e két fajtájával, azok tulajdonságaival és kapcsolatával foglalkozott. Greif (2005b) az intézmények csoportosításában a fentiek szerint két kategóriát különít el: szerződést kikényszerítő intézményeket ('Contract Enforcing Institutions') és a kikényszerítő hatalmat korlátozó intézményeket ('Coercion Constraining Institutions'). A szerződést kikényszerítő intézmények elengedhetetlenek a piacok fejlődéshez, ahogy azt a középkori Európa példáján láttuk. Ezek egy szempontból lehetnek állami (törvények, szabályozások) vagy magán intézmények (tőzsdék, áruházláncok, stb.), más szempontból spontán módon kialakult (szokások, normák) vagy tudatosan létrehozott intézmények. Greif szerint a kikényszerítő hatalmat korlátozó intézmények határozzák azt meg, hogy egy piac hogyan fejlődik, ezek különbségei vezetnek a különböző fejlődési pályákhoz. Az ugyanis, hogy az állam mennyire képes hatékony szerződést kikényszerítő intézményeket „kínálni”, a kikényszerítő hatalmat (államot) korlátozó intézményektől függ. Ez azt jelenti, hogy a piac fejlődésének kérdése - amelyet a szerződést kikényszerítő intézmények határoznak meg - közvetlenül kapcsolódik egy szélesebb kérdéskörhöz, a kikényszerítö hatalmat korlátozó intézményekhez. Ez utóbbiak hatékonysága pedig kapcsolatos azzal, hogy lesz-e terük a maffiaszerü csoportoknak.

Greif intézményi közgazdaságtani kutatásait természetesen nem a maffia megértésének szándéka motiválta. Sőt, azok számára, akik ismerik a professzor munkásságát, első ránézésre talán merésznek is tűnik a maffiával való asszociáció. Remélem azonban, hogy a fentiek két dologról győznek meg bennünket. Egyrészt arról, hogy az intézményi közgazdaságtan sokkal több probléma megértésében segíthet, mint azt korábban gondoltuk. Másrészt arról, hogy a szervezett bűnözés közgazdaságtana valójában ugyanazokat az eszközöket használja, mint a mainstream közgazdaságtan (formális elemzés). ${ }^{14}$ Ez utóbbit tovább erősítette Avinash Dixit professzor három előadása.

12 A személytelen csere azt jelenti, hogy a tranzakció nem függ (1) sem az aktuális partnerek közötti interakciók jövőbeli várt előnyeitől, (2) sem a múltbeli magatartásoktól, (3) sem attól, hogy a felek jövőbeli „rossz" magatartását milyen jól lehet felfedni.

13 Az egyensúly formális levezetését lásd: Greif (2005c).

14 Hiszen Greif történelmi példáit formális modellekbe foglalja. 


\section{Irányítási struktúrák és a maffia}

Dixit professzor a szervezett bünözést az irányítási intézmények ('governance structures') szélesebb kontextusában helyezte el (Dixit 2003). Kiindulópontja az, hogy minden tranzakció, kivéve a spot piaci cserét, magában hordozza annak kockázatát, hogy valamelyik fél a másik kárára csal. Ezért a tranzakciók lebonyolítása valamilyen irányítási formát igényel, különben a csalás lehetősége miatt a tranzakció nem jönne létre. A legtöbb elmélet azt feltételezi, hogy a tökéletesen és költségmentesen működő jogrendszer biztosítja a megfelelő irányítási módot. A jogrendszer azonban nem működik tökéletesen, elég csak a korrupcióra gondolni, de nem is költségmentes a használata, hiszen sokszor a harmadik fél számára erőforrásokat igényel a szerződések betartásának ellenőrzése. A kérdés tehát az, hogy léteznek-e olyan alternatív irányítási módok, amelyek ugyanolyan jók, mint a törvényes jog, vagy esetleg jobbak.

Dixit professzor figyelme az alternatív irányítási módok közül az önirányításra ('self-governance') irányul, melyet ismételt interakciók közötti egyensúlyként modellez egy nagyszámú populációban. Aszimmetrikus fogolydilemma helyzetet ábrázol, ahol a játékosok háromféle magatartást tanúsíthatnak: becsületes, becstelen és opportunista magatartást. A modell kilenc különböző egyensúlyi helyzetet határoz meg attól függően, hogy a szereplök milyen magatartást mutatnak. Ezek között vannak olyan helyzetek, amelyekben egy profitalapon működő magán közvetítő (ez lehet például a maffia) képes a társadalmi hatékonyságot javítani.

Ennek fényében érdemes figyelmünket ezekre a szituációkra összpontosítani. A magán közvetítő szerepe az, hogy információt szolgáltasson a korábban csalárd magatartást tanúsítókról. Ez a személy szerződéses viszonyban áll az egyénekkel. A probléma az, hogy ő is csalhat. Dixit professzor modelljébe beépíti az információs közvetítőt és annak lehetséges magatartását is, majd egy olyan közvetítőt is, aki képes a kikényszerítésre. A formális modellből számos következtetés adódik, többek között az, hogy ha bekapcsolódik a magán közvetítő, a kialakuló egyensúlyban nagyobb arányban lesznek a becsületes aktorok, és javul a társadalmi hatékonyság.

Nyilvánvaló, hogy hasonlóan Greif elméletéhez, a fenti sem a maffia megértése okán született meg. A legtöbb esetben a modellben kulcsszerepet játszó magán közvetítő nem a maffia, hanem valamilyen piaci intézmény (bank, cégbíróság, ügyvédek). A maffia éppen akkor lép színre, ha ezek a piaci magán közvetítők hiányoznak. ${ }^{15}$ Ilyen esetekben viszont, a modell alapján, a maffia tevékenysége növeli a társadalmi hatékonyságot.

${ }^{15}$ A legjobb példa erre Japán. A Jakuza tevékenységének legnagyobb része megfelel a dixiti modell magánközvetítöjének: hitelek behajtása, információk a rossz adósokról, banki hitelek "kijárása”. E tevékenységek pedig éppen azért maffiatevékenységek, mert Japánban gyengék a nem-maffia magánközvetítók: relative alacsony az ügyvédek és közjegyzők száma, a sajátos bankrendszer miatt nehéz banki hitelekhez jutni, stb. Lásd erröl részletesen: (Milhaupt - West 2000). 


\section{Hivatkozások}

Dixit, A. (2003): On Modes of Governance. Econometrica, 71. évf. 2. sz. 449-481.

Gambetta, D. (1993): The Sicilian Mafia: the Business of Private Protection. Harvard Unidersity Press, Cambridge.

Greif, A. (2005a): Building a State: Genoa's Rise and Fall. In: Greif, A.: Institutions and the Path to the Modern Economy: Lessons from Medieval Trade. Cambridge University Press, Cambridge. (Megjelenés alatt)

Greif, A. (2005b): Commitment, Coercion, and Markets: The Nature and Dynamics of Institutions Supporting Exchange. In: Ménard, C. - Shirley, M. (eds.): Handbook of New Institutional Economics. Springer, 727-786.

Greif, A. (2005c): The Institutional Foundations of Impersonal Exchange. In: Greif, A.: Institutions and the Path to the Modern Economy: Lessons from Medieval Trade. Cambridge University Press, Cambridge. (Megjelenés alatt)

Milhaupt, C. J. - West, M. D. (2000): The Dark Side of Private Ordering: An Institutional and Empirical Analysis of Organized Crime. The University of Chicago Law Review, 67. évf. 1. sz. 41-97. 